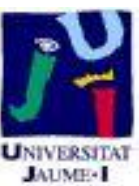

Título artículo / Títol article: Trends of arsenic levels in PM10 and PM2.5 aerosol in an industrialized area

Autores / Autors

J.R. García-Aleixa, Juana María Delgado Saborit, G. Verdú-Martín, J.M. Amigó-Descarrega, Vicente José Esteve Cano

Revista:

Environmental Science and Pollution Research, 2014, vol. 21, núm. 1

Versión / Versió:

Pre-print

Cita bibliográfica / Cita bibliogràfica (ISO 690):
García-Aleixa, J.R. ; Delgado Saborit, Juana María ; Verdú-Martín, G. ; Amigó-Descarrega, J.M. ; Esteve Cano, Vicente José. Environmental Science and Pollution Research, 2014, vol. 21, núm. 1, p. 695703

url Repositori UJI: http://hdl.handle.net/10234/91500 


\section{Trends of arsenic levels in PM10 and PM2.5 aerosol in an industrialized area}

J.R. García-Aleix ${ }^{\mathrm{a}}$, J.M. Delgado-Saborit ${ }^{\mathrm{b}}$, G. Verdú-Martín ${ }^{\mathrm{a}}$, J.M. Amigó-Descarrega ${ }^{\mathrm{c}}, \mathrm{V}$. Esteve-Cano ${ }^{\mathrm{d}, *}$

${ }^{a}$ Departamento de Ingeniería Química y Nuclear, Universidad Politécnica de Valencia $\mathrm{C}^{\mathrm{o}}$. de Vera, s/n, 46022 Valencia, Spain.

${ }^{\mathrm{b}}$ Univ Birmingham, Div Environm Health \& Risk Management, Sch Geog Earth \& Environm Sci, Birmingham B15 2TT, W Midlands England

${ }^{c}$ Departamento de Geología, Universitat de València, Av. Dr. Moliner, s/n, 46100 Burjassot, Spain.

${ }^{\mathrm{d}}$ Departamento de Química Inorgánica y Orgánica, Universitat Jaume I, Ap. 224, 12071 Castellón, Spain.

*Corresponding author. Tel. +34-964-728246; fax +34-964-728214.

E-mail address: vicente.esteve@uji.es

Keywords: Arsenic, Atmospheric particles, PM2.5, PM10, Ceramic industry. 


\begin{abstract}
Arsenic is a toxic element that affects human health and it is widely distributed in the environment. In the area of study, the main Spanish and second European industrial ceramic cluster, the main source of arsenic aerosol is related to the impurities in some boracic minerals used in the ceramic process. Epidemiological studies on the cancer occurrence in Spain points out the study region as one with the greater risk of cancer. Concentrations of particulate matter and arsenic content in $\mathrm{PM}_{10}$ and $\mathrm{PM}_{2.5}$ have been measured and characterised by ICP-MS in the area of study during the years 2005-2010. Concentrations of $\mathrm{PM}_{10}$ and arsenic range $27-46 \mu \mathrm{g} / \mathrm{m}^{3}$ and $0.7-6 \mathrm{ng} / \mathrm{m}^{3}$ respectively in the industrial area, and $25-40 \mu \mathrm{g} / \mathrm{m}^{3}$ and $0.7-2.8 \mathrm{ng} / \mathrm{m}^{3}$ in the urban area. Concentrations of $\mathrm{PM}_{2.5}$ in the urban are range 12 to $14 \mu \mathrm{g} / \mathrm{m}^{3}$ and 0.5 to $1.4 \mathrm{ng} / \mathrm{m}^{3}$ in the urban background area. Most of the arsenic content is present in the fine fraction, with ratios of $\mathrm{PM}_{2.5} / \mathrm{PM}_{10}$ in the range 0.65 to 0.87 . The $\mathrm{PM}_{10}, \mathrm{PM}_{2.5}$ and its arsenic content show a sharp decrease in recent years associated with the economic downturn, which hit severely the production of ceramic materials in the area under study. The production decrease due to the economic crisis combined with several technological improvements in recent years such as substitution of boron, which contains As impurities as raw material, have reduced the concentrations of $\mathrm{PM}_{10}, \mathrm{PM}_{2.5}$ and $\mathrm{As}$ in air to a extent that currently met the existing European regulations.
\end{abstract}




\section{Introduction}

Arsenic is a toxic element that affects human health (Jomova et al 2011) and hence, the study of arsenic in environmental media (i.e., groundwater, soil, and air) and the associated human health risks has been an active area of research for many decades (Lewis et al 2012). Arsenic is widely distributed in the environment. Its abundance ranks twentieth in the Earth's crust, with mean concentration of $1.6 \mu \mathrm{g} \cdot \mathrm{g}^{-1}$ (Holmes and Miller 2004); fourteenth in seawater and twelfth in the human body (Mandal and Suzuki 2002; Jomova et al 2011).

Plenty of studies have studied human exposures to arsenic in drinking water and its adverse health effects due to the relatively high concentrations of naturally occurring arsenic in drinking water in some parts of the world. Similarly, the exposure of arsenic arising from soils nearby mining and smelting activities has also been paid attention (Lewis et al 2012). On the other hand, exposures associated with arsenic in ambient air are more scarce. Nonetheless, high concentrations of arsenic and other potentially toxic elements of environmental interest may be present in the atmospheric aerosol (Sanchez de la Campa et al 2011). Anthropogenic sources are often related with combustion of fossil fuels as burning coal, copper smeltering and incineration of municipal waste (Pacyna et al 2007; FernandezCamacho et al 2010). Arsenic is also released to the atmosphere from other smelting metals, use of some pesticides and some glass raw materials (Sanchez de la Campa et al 2011). Arsenic aerosol has also been associated with terrestrial crustal, volcanoes and groundwater origin (Sanchez de la Campa et al 2011). Nevertheless, anthropogenic emissions of arsenic to the atmosphere are about three times higher than natural ones (WHO 2000).

In the area of study, which is the main Spanish and second European industrial ceramic cluster (Delgado-Saborit and Esteve-Cano 2007), the main source of arsenic aerosol is related to the ceramic industry. Arsenic is present as an impurity in some boracic minerals, 
namely colemanite, hydroboracite and ulexite, which are widely used for reducing melting point of the ceramic frits (Esteve and Ramos 1999). Vickery et al (1998) calculated that volatile losses of arsenic trioxide during the ceramic process were in the range of $0.15-0.21$ $\mathrm{mg} \mathrm{g}^{-1}$ of frit for colemanite and $0.03-0.07 \mathrm{mg} \mathrm{g}^{-1}$ of frit for hydroboracite (Vickery et al 1998). These very high values highlight the importance of the use of boracic minerals in the ceramic industry as an important source of airborne arsenic in the study area and the possible impact in the exposure to arsenic for the local population.

Arsenic is considered as one of the most toxic elements for human health (Chappell et al 2003). Continued exposure to a high concentration of arsenic may produce acute toxic effects on humans, which can be quickly diagnosed. However, chronic exposure to low doses of arsenic may give rise to cancer (Hayes 1997; Roy and Saha 2002; IARC 2009). Arsenic is recognised as a carcinogenic element producing skin, lung and urinary bladder cancer (Englyst et al 2001; Cantor and Lubin 2007). In 2000, the World Health Organization (WHO 2000) Air Quality Guidelines for Europe calculated $1.5 \times 10^{-3}$ cancer risk for a lifetime exposure to a concentration of $1 \mu \mathrm{g}^{-3} \mathrm{~m}^{-3}$ (WHO 2000). Several epidemiological studies and the Ariadna Data Base show that the region of Castellón, where the study area is located, holds the $5^{\text {th }}$ and $9^{\text {th }}$ position in incidence of urinary bladder cancer and lung cancer respectively in Spain (Centro Nacional de Epidemiología (CNE) 2011). Both cancers are related with arsenic exposure (Englyst et al 2001; Cantor and Lubin 2007). The map of cancer occurrence in Spain points out the study region as one with the greater risk of cancer of all Spain (Benach et al 2003). On the other hand, besides promoting various types of cancer, arsenic produces other adverse effects on human health, such as hypertension, cardiorespiratory disease (Navas-Acien et al 2005), immunological system disease (Duker et al 2005), diabetes (Diaz-Villasenor et al 2007), neurological disorders (Vahidnia et al 2007) and dermal effects (Cohen et al 2006).

Given the health effects and its ubiquity in the atmosphere, airborne arsenic 
aerosol is nowadays a pollutant of major interest in EU. Arsenic and its ambient air concentration in $\mathrm{PM}_{10}$ are regulated by the EU Directive 2004/107/EC of the European Parliament and of the Council of 15 December 2004 relating to arsenic, cadmium, mercury, nickel and polycyclic aromatic hydrocarbons in ambient air. This Directive proposed a target value for arsenic in $\mathrm{PM}_{10}$ of $6 \mathrm{ngm}^{3}$ as an annual mean to be met from-December 2012. No limits are established for arsenic on $\mathrm{PM}_{2.5}$. On the other hand, the WHO guidelines on arsenic exposure estate that a safe level for inhalation exposure cannot be recommended (WHO 2000).

The present work builds on previous studies by Querol and coworkers that characterized the quality of the air in the ceramic cluster area of Castellón (Querol et al 2001) and compared it with other Spanish cities (Querol et al 2004a; Querol et al 2004b; Querol et al 2008).Those studies showed the occurrence of relatively high ambient air concentrations of arsenic in $\mathrm{PM}_{10}$ in the area of study. However no data on arsenic content in $\mathrm{PM}_{2.5}$ was reported, which has a higher potential of penetration in the respiratory system. The cited Querol studies were performed in the early part of the noughties. Since then several technical actions have been implemented by the ceramic industry to reduce the content of arsenic in the air. Considering a) the outlined health effects in the area of study, b) the technological actions implemented c) the higher potential of penetration of $\mathrm{PM}_{2.5}$ in the respiratory system and d) the recent economic downturn on the ceramic industry undergoing a period of severe reduction in its manufacturing output; there is the need of reassessing the levels and trends of arsenic in $\mathrm{PM}_{10}$ and characterising the content of arsenic in $\mathrm{PM}_{2.5}$ in the ceramic area of interest.

The aim of this work focuses on characterising the levels and trends from 2006 to 2010 of arsenic on $\mathrm{PM}_{10}$ and $\mathrm{PM}_{2.5}$ and to assess the compliance with the 2004/107/EC Directive in the ceramic industry study area. 


\section{Materials and Methods}

\subsection{Area of study}

Samples were collected in two sites located in L'Alcora (Easter Spain), a city which is located within the ceramic industry cluster. The cluster is a geographical triangle of $300 \mathrm{~km}^{2}$ containing more than 200 ceramic industries producing $94 \%$ and $43 \%$ of the Spanish and the European tiles respectively (Querol-Balaguer et al 2004; Delgado-Saborit and Esteve-Cano 2007). Further details of the area of study can be found in Delgado-Saborit and Esteve-Cano (2007).

\subsection{Aerosol sampling and sample preparation}

$\mathrm{PM}_{10}$ and $\mathrm{PM}_{2.5}$ samples were collected in two sampling sites at L'Alcora. The first site (Site 1- Industrial) was located near a municipal sports center within an industrial area $\left(0^{\circ} 12^{\prime} 24^{\prime \prime}\right.$ $\mathrm{W}, 40^{\circ} 4{ }^{\prime} 05^{\prime \prime} \mathrm{N}, 240 \mathrm{~m}$ asl). The second site (Site 2-Urban Background) was located in a retirement home $\left(0^{\circ} 12^{\prime} 44^{\prime \prime} \mathrm{W}, 40^{\circ} 4{ }^{\prime} 25^{\prime \prime} \mathrm{N}, 260 \mathrm{~m}\right.$ asl $)$, considered as urban background. At the first station, $\mathrm{PM}_{10}$ sampling was carried out by means of a medium volume Partisol sampler model 2000-H (Rupprecht and Patashnick, USA) furnished with a $\mathrm{PM}_{10}$ inlet, operating at $2.3 \mathrm{~m}^{3} \mathrm{~h}^{-1}$. At the second station, $\mathrm{PM}_{10}$ samples were collected using a high volume sampler model MCV-AV model (MCV, Spain), operating at $30 \mathrm{~m}^{3} \mathrm{~h}^{-1}$ furnished with a Digitel $\mathrm{PM}_{10}$ inlet. $\mathrm{PM}_{2.5}$ samples were collected using a medium volume sampler (Derenda Medium Volume Sampler Model MV 56.1 LV53.1, Germany) furnished with a $\mathrm{PM}_{2.5}$ inlet. All sampling equipment was made of non-contaminating materials such as anodised aluminium, stainless steel, polyethylene and polypropylene.

Wahtman GF/A $150 \mathrm{~mm}$ (for MCV sampler) and Whatman QMA $47 \mathrm{~mm}$ (R\&P and Derenda samplers) quartz glass microfiber filters were used as media collection. During a 5 
year period from $01 / 03 / 2006$ to $31 / 12 / 2010$ a total of 3,272 24-h samples were collected, in which 1,241 were $\mathrm{PM}_{10}$ samples collected at site 1 (industrial); whilst $1,310 \mathrm{PM}_{10}$ and 721 $\mathrm{PM}_{2.5}$ samples at site 2 (urban background). At the end of every 24-h sampling period, the aerosol samples were sealed in plastic bags and were brought back to the laboratory for chemical analysis. In the laboratory, samples were conditioned $\left(20 \pm 1^{\circ} \mathrm{C} ; 50 \pm 5 \%\right.$ humidity $)$ for 24 hours in a dessicator before weighting. For chemical analysis, one sample corresponding with a day per week was selected randomly for every sampler, therefore a total of three samples per day were selected. A total of $275 \mathrm{PM}_{10}$ and $99 \mathrm{PM}_{2.5}$ samples were analysed.

\subsection{Elemental analysis}

Elemental analysis of $\mathrm{PM}_{10}$ and $\mathrm{PM}_{2.5}$ was performed. After gravimetric determination of PM levels, filters were digested in an acid media $\left(\mathrm{HNO}_{3}, 65 \%\right.$, J. T. Baker and $\mathrm{H}_{2} \mathrm{O}_{2}, 33 \%$, PA-ACS-ISO). Extractions were carried out with $10 \mathrm{~mL}$ of acid and $10 \mathrm{~mL}$ of MQ ultrapure water, using Teflon jars and a Merck microwave oven (Esteve and Peris 2000). Once samples were digested, arsenic levels were analysed with an Inductively Coupled PlasmaMass Spectrometrer, (ICP-MS Agilent 7500 CX with collision cell). The Limit of Detection for arsenic was $0.0073 \mu \mathrm{g} \cdot \mathrm{g}^{-1}$.

The QA/QC protocol consisted in analysing a blank filter in each batch of samples. For determine possible arsenic traces in reagents and quartz glass filters, blank filters were analysed simultaneously in the batch of their respective samples. Extraction efficiency was assessed by analysing a sample of the certified reference material SRM 1648 (urban particulate matter standard) (NIST, Gaithersburg, MD, USA). 


\section{Results and discussion}

\section{1. $P M_{10}$ and $P M_{2.5}$ concentrations}

Table 1 shows the annual averages of $\mathrm{PM}_{10}$ (industrial and urban sites) and $\mathrm{PM}_{2.5}$ (urban site) and the number of exceedances of the current regulation per year. The values of $\mathrm{PM}_{10}$ measured in the urban background site during the period 2006-2010 are similar, albeit decreasing, to those reported previously by Querol et al for the same area for the period 2002-2005 (Querol et al 2007). The values measured at the industrial station are higher than those measured at the urban background site (Table 1), which reflects the influence of the ceramic industry emissions on the site. The levels measured at the background and industrial site are consistent with values reported for other areas in Spain, wich levels ranging 30-40 $\mu \mathrm{g} \cdot \mathrm{m}^{-3}$ in urban background sites, and levels in the range of $46-50 \mu \mathrm{g} \cdot \mathrm{m}^{-3}$ in industrial areas (Querol et al 2008).

Levels of $\mathrm{PM}_{2.5}$ measured at the area of interest (Table 1) are lower than those measured at other urban background areas in Spain, which range 20 to $30 \mu \mathrm{g} / \mathrm{m}^{3}$, whilst they are similar to those measured at rural background areas $\left(\mu \mathrm{g} / \mathrm{m}^{3}\right)$ in Spain (Querol et al 2008), Puerto Rico (Figueroa et al., 2006), but lower than $\mathrm{PM}_{2.5}$ levels in Italy (Marcazzan et al 2001), China (Ho et al 2002) or Taiwan (Fang et al 1999).

The decreasing pattern of $\mathrm{PM}_{10}$ and $\mathrm{PM}_{2.5}$ measured during the study period reflect the effect of the combination of measures that the ceramic manufactures had already set in place in previous years (Celades et al 2012). Nonetheless, this decreasing trend might also the attributed to the fact that the economic crisis hit considerably the ceramic sector with a strong reduction in manufacturing, which has halved the production to levels similar to those experienced in 1995 (Celades et al 2012). This is consistent with a recent study which documented that levels of PM10 followed a similar trend of economic indicators (Arruti et al 
2011).

To assess the degree of compliance in the area of study for the period 2006-2010, the concentrations measured of $\mathrm{PM}_{10}$ and $\mathrm{PM} 2.5$ were compared with the guidelines given in the European Directive 2004/107/CE of the European Parliament on ambient air quality; the Directive 2008/50/EC of the European Parliament and of the Council of 21 May 2008 on cleaner air for Europe and the Spanish R.D. 102/2011.

Annual $\mathrm{PM}_{10}$ levels in the industrial site were higher than the limit value proposed by the European Directive 1999/30/EC (i.e. annual average below $20 \mu \mathrm{g} / \mathrm{m}^{3}$ and a maximum of 7 exceedances of the level of $50 \mu \mathrm{g} / \mathrm{m}^{3}$ per year). However, the $\mathrm{PM}_{10}$ levels measured in 2009 and 2010 at the urban background site would meet the new European Directive 2008/50/EC and Spanish regulation R.D. 102/2011, which sets a limit value for $\mathrm{PM}_{10}$ of $40 \mu \mathrm{g} / \mathrm{m}^{3}$ with a maximum of 35 exceedances per year of the value $50 \mu \mathrm{g} / \mathrm{m}^{3}$. The same regulation established a limit annual value for $\mathrm{PM}_{2.5}$ of $25 \mu \mathrm{g} / \mathrm{m}^{3}$, which has been met in the area of study. It is likely that if the values of $\mathrm{PM}_{2.5}$ remain similar in the area of study, the $\mathrm{PM}_{2.5}$ values will continue to be within the values established in the current regulation.

\subsection{Arsenic content in $P M_{10}$ and $P M_{2.5}$}

Levels of arsenic in the atmosphere are varied. In remote and rural areas, the mean arsenic airborne concentrations range from 0.02 to $4 \mathrm{ng} \cdot \mathrm{m}^{-3}$ (WHO 2000), whilst in urban areas arsenic concentrations range from 3 to about $200 \mathrm{ng} \cdot \mathrm{m}^{-3}$ (Querol et al 2007; Halek et al 2010; von Schneidemesser et al 2010). Typical $\mathrm{PM}_{10}$ arsenic levels in European Union countries are currently between 0.2 and $1.5 \mathrm{ng} \cdot \mathrm{m}^{-3}$ in rural areas, 0.5 and $3 \mathrm{ng} \cdot \mathrm{m}^{-3}$ in urban areas and lower than $50 \mathrm{ng} \cdot \mathrm{m}^{-3}$ in industrial areas (Putaud et al 2004). Querol et al (2004b) reported arsenic $\mathrm{PM}_{10}$ levels for rural, urban and some industrial sites in Spain in the range of $0.3,0.3-1.8$ and $5 \mathrm{ng} \cdot \mathrm{m}^{-3}$, respectively. Table 2 presents the aritmetic mean, maximum and minimum concentration of arsenic found in $275 \mathrm{PM}_{10}$ samples and $99 \mathrm{PM}_{2.5}$ samples 
randomly selected to represent the entire sampling period 2005-2010 at both sampling sites.

The mean arsenic content of the $181 \mathrm{PM}_{10}$ samples analysed representative of the period 2005-2007 in both sampling sites $\left(3.33 \mathrm{ng} \cdot \mathrm{m}^{-3}\right.$ at industrial site and $2.25 \mathrm{ng} \cdot \mathrm{m}^{-3}$ at urban background site), is above the usual range of levels $\left(0.3-1.8 \mathrm{ng} \cdot \mathrm{m}^{-3}\right)$ found in urban background in other Spanish cities (Querol et al 2004b), with the exception of Huelva industrial area, that shows larger values. On the other hand, arsenic levels representative of the period 2008-2010, are below the Spanish average arsenic content $\left(0.99 \mathrm{ng} \cdot \mathrm{m}^{-3}\right.$ at industrial site and $0.93 \mathrm{ng} \cdot \mathrm{m}^{-3}$ at urban background site) coinciding with the economic crisis.

For comparison, concentration of arsenic in $\mathrm{PM}_{10}$ measured at two rural background monitoring stations are $0.05-0.35 \mathrm{ng} \cdot \mathrm{m}^{-3}$ in San Jorge and $0.35-0.7 \mathrm{ng} \cdot \mathrm{m}^{-3}$ in Cirat. These villages are located at $90 \mathrm{~km}$ and $40 \mathrm{~km}$ from L'Alcora, respectively. The $\mathrm{PM}_{10}$ concentrations at these locations, which are not influenced by the emissions of the ceramic smelter industries, are lower than those found at L'Alcora in the present study and those found at other Spanish urban monitoring stations (Querol et al 2004b). Previous studies of arsenic content in $\mathrm{PM}_{10}$ in the area of study showed higher levels than actual with $16 \mathrm{ngm}^{-3}$ in 2002 (Pallares et al., 2007), $9.9 \mathrm{ng}^{-3}$ in 2003, $6 \mathrm{ngm}^{-3}$ in 2004 and $2.5 \mathrm{ng}^{-3}$ in 2005 (Minguillón et al 2009). The lower concentration of airborne arsenic in $\mathrm{PM}_{10}$ measured since 2004 are associated with the introduction of several technical actions, such as the substitution of colemanite used as additive by the local frit industry (Esteve and Ramos, 1999), which was the main source of arsenic as an impurity (Arslan et al 1999). Actual measured levels are within the same range of concentration than those measured in another similar industrial area in Greece $\left(1.9 \mathrm{ngm}^{-3}\right.$ in PM2.5 and $1.1 \mathrm{ng}^{-3}$ in PM10 in 2006) (Tsopelas et al 2008). On the other hand, arsenic content of $\mathrm{PM}_{10}$ and $\mathrm{PM}_{2.5}$ are lower than those measured in industrial zones in Murano (Italy) with values as high as $60 \mathrm{ngm}^{-3}$ in $\mathrm{PM}_{10}$ in 2003 (Rampazzo et al 2008). The levels measured in the area of study are also lower than those reported in another urban-industrial area in Huelva (Spain) with average arsenic 
levels in $\mathrm{PM}_{10}$ and $\mathrm{PM}_{2.5}$ ranging between 4.7-11 and 3.0-9.2 $\mathrm{ng}^{-3}$ respectively and maximum arsenic content in $\mathrm{PM}_{10}$ and $\mathrm{PM}_{2.5}$ in the range of 22-62 and 19-60 $\mathrm{ng}^{-3}$ during the period 2004-2005 (Fernandez Camacho et al 2010).

The European Directive 2004/107/EC establishes a target value for arsenic of 6 $\mathrm{ng} / \mathrm{m}^{3}$ to be met by 2013 . If the concentrations of airborne arsenic remain similar to those measured during the study period (2006-2010), it is very likely that the arsenic target value will be met in 2013 .

\subsection{Ratios of As in PM: As-PM2,5; As-PM10 and As-PM(10-2,5)}

The ratios of $\mathrm{PM}_{2.5}$ to $\mathrm{PM}_{10}$ and to coarse fraction (i.e. $\mathrm{PM}_{10}-\mathrm{PM}_{2.5}$ ) at the urban site for the years 2007-2010 are presented in Table 3. The arsenic $\mathrm{PM}_{2.5} / \mathrm{PM}_{10}$ ratio ranges between 0.65 and 0.87 for the urban site (Table 3), whilst the $\mathrm{PM}_{2.5} /\left(\mathrm{PM}_{10}-\mathrm{PM}_{2.5}\right)$ ratio varies between 1.9 and 6.8, for the urban site, which also indicates the accumulation of arsenic in the fine size particles. This values shows that most of the arsenic content of the aerosol is be found in the finer fraction $\mathrm{PM}_{2.5}$. This represents a risk for human health, since the smaller the diameter of the particle, the greater capacity to enter the organism through the respiratory system (Sanchez-Rodas et al 2012). Heatland et al (2000) suggested that metal particles could play a role in the induction of inflammation and cytotoxity in the human epithelial cells (Hetland et al 2000).

Table 3 shows an enrichment of the content of arsenic on the fine fraction during years 2009 and 2010 similar to the enrichment of fine particulate matter in $\mathrm{PM}_{10}$. It can also be observed that the ratios from 2007-2008, prior to the economic downturn are significantly different $(p<0.005)$ than the ratios from 2009-2010. The concentration of arsenic in the fine size fraction of the PM is consequence of the combustion processes in the frit process (Vickery et al 1998). Therefore the evolution of the fine fraction will be mainly linked to the 
evolution of the frit production. The ceramic tile production in 2007-2008 was $550 \mathrm{M}$ $\mathrm{m}^{2}$ /year, whist during 2009 and 2010, this figure decreased to circa $350 \mathrm{M} \mathrm{m}^{2} /$ year (Celades et al 2012). Nonetheless, the impact of the decay of manufacturing, is expected to affect similarly the content of $\mathrm{PM}_{10}$ and $\mathrm{PM}_{2.5}$ as observed in Table 1 and Table 2. Eventually, the enrichment of the fine fraction and the arsenic content of the fine fraction is related with a decreased of the emission of $\mathrm{PM}_{10}$. The main source of $\mathrm{PM}_{10}$ in the ceramic industry is linked with fugitive emissions from storage and handling of raw materials (Minguillon et al 2009). From 2001 to 2007, abatement technologies were implemented and the situation changed from 2001 where practically all companies stored the raw materials outdoors, to 2007 where over 50\% stored their raw materials in closed compartments. In recent years the handling and storage of raw materials has continued to increased and many companies have installed corrective measures as well. As a results the concentrations of fugitive emissions of $\mathrm{PM}_{10}$ have decreased significantly.

\subsection{Seasonal pattern}

In order to identify possible seasonal variations of arsenic in $\mathrm{PM}_{10}$ and $\mathrm{PM}_{2.5}$ at the two sampling sites, the seasonal levels of arsenic in $\mathrm{PM}_{10}$ and $\mathrm{PM}_{2.5}$ for the period (2006-2010) has been plotted in Figure 1.

Figure 1 does not show a clear seasonal pattern. This may indicate that the arsenic airborne concentrations are mainly related with the industrial production of ceramic products. This suggestion is supported by the fact that the maximum arsenic values occur at random order across all the months during the period of study (Table 4). The lack of a seasonal pattern and the randomness on the maxima values suggests a prevalence of the industrial origin of airborne arsenic levels in the area of study. 


\subsection{Evolution in levels of arsenic in the period 2006-2010}

Figure 2 shows the monthly evolution of arsenic content in $\mathrm{PM}_{10}$ and $\mathrm{PM}_{2.5}$ during the period 2006-2010 at an industrial and urban background site within the ceramic industrial cluster.

Figure 2 shows a zigzag pattern, which may be due to the batch mode operation of smelters that operate with different quantities of raw material containing variable contents of arsenic. This zigzag pattern has been previously related with a clear industrial origin (Sanchez de la Campa et al 2008).

Figure 2 also shows a gradual decrease in the levels of arsenic across the period of study, albeit the major reductions can be observed prior to 2008. This sharper decrease can be attributed to the introduction of cleaner raw materials in the frit fusion kilns, which used colematines with lower content of arsenic (Arslan et al 1999; Karagolge et al 2002).

The second sharpest decline occurred in 2008 when the economic crisis first struck Spain and the ceramic production decreased significantly. A steady decrease is observed in the years 2009 and 2010 in which the economic crisis in Spain hit very strongly the construction sector, which was the main customer of ceramic materials, affecting consideratbly the production of ceramic industries settled in the study area. The concentrations of arsenic in PM levels measured during the economic crisis years are significantly lower $(\mathrm{p}<0.001)$ than concentrations measured before the economic crisis.

Figure 3 shows the evolution between 2006-2010 of annual average levels of arsenic $\left(\mathrm{ngm}^{-3}\right)$ in other locations belonging to the ceramic cluster of Castellón, which spans an area of $300 \mathrm{~km}^{2}$ with a population of 400,000 inhabitants. Data was obtained from the regional air quality monitoring network (i.e Conselleria de Medio Ambiente de la Generalitat Valenciana) in the sites located in L'Alcora, Onda, Vila-real, Burriana and Castellón. Onda and Vila-real are industrial cities like L'Alcora, Burriana is a coastal town 
mainly agricultural and Castellón is a major urban and coastal city (165,000 inhabitants).

Figure 3 follows a similar trend than that shown in Figure 2, with arsenic levels declining in all cities within the ceramic cluster area. This suggests that the decline in arsenic emissions is generalised in all the ceramic manufacturing area, and that this reduction is benefiting also population located in nearby non-industrial cities such as Burriana and Castellon. The fact that Burriana shows the highest levels of arsenic in aerosol might be attributed to the use of lead arsenates as pesticides (He et al 2005) in the orange tree orchads, the main economic resource of that city and in the fact that Burriana is located downwind of the ceramic emissions (Querol et al 2007).

If we compare the reduction of arsenic levels with the decrease in sales of ceramic materials such as tiles and flooring (Figure 4), we can observe a strong correlation between both variables that clearly indicates the dependence on arsenic levels in the production industry in the area under study. Similary to the downward trend observed for the As content in PM, Table 1 shows a decrease in $\mathrm{PM}_{10}$ and $\mathrm{PM}_{2.5}$ levels that mirrors the reduction in ceramic sales.

The combination of a) the zig-zag pattern in arsenic content levels; b) the relationship between particulate matter and arsenic content in air with ceramic sales; and c) the use of boron compounds (such as colemanite, hyydroboracite and ulexite) in the production of frits (a raw material in tile manufacturing) reinforces the suggestion that the ceramic industry is the main source of airborne arsenic in the area of study.

\section{Conclusions}

The local ceramic manufacturing activity, specially that related to the smelters using boron compounds as raw materials, is suggested to be responsible for the arsenic airborne levels found in $\mathrm{PM}_{10}$ and $\mathrm{PM}_{2.5}$ in the study area (L'Alcora) and surrounding cities within the 
ceramic cluster area.

The $\mathrm{PM}_{10}, \mathrm{PM}_{2.5}$ and its arsenic content have shown a sharp decrease in recent years associated with the economic downturn, which hit severely the production of ceramic materials in the area under study. The production decrease due to the economic crisis combined with several technological improvements in recent years (e.g. substitution of boron which contains As impurities as raw material) have reduced the concentrations of $\mathrm{PM}_{10}$, $\mathrm{PM}_{2.5}$ and $\mathrm{As}$ in air to a extent that currently met the existing European regulations. When ceramic production boost again, it is advisable that technological improvements are considered to ensure that the the particulate matter and arsenic concentrations continue to met the regulations.

\section{Acknowledgements}

Authors are grateful to Ilmo. Ayuntamiento de L'Alcora for financial support through the 07I055 project, Generalitat Valenciana for their support and collaboration and Miss Miriam Rubio Renau for her assistance in laboratory work. 


\section{REFERENCES}

Arruti A, Fernandez-Olmo I and Irabien A. Impact of the global economic crisis on metal levels in particulate matter $(\mathrm{pm})$ at an urban area in the cantabria region (northern spain). Environmental Pollution 2011; 159:1129-1135.

Arslan F, Arslan C and Celik MS. Arsenic removal through the decrepitation of colemanite ores. Powder Technol 1999; 103:260-264.

Benach J, Yasui Y, Borrell C, Rosa E, Pasarin MI, Benach N, et al. Examining geographic patterns of mortality: The atlas of mortality in small areas in spain (1987-1995) The European Journal of Public Health 2003; 13:115-123.

Cantor KP and Lubin JH. Arsenic, internal cancers, and issues in inference from studies of low-level exposures in human populations. Toxicology And Applied Pharmacology 2007; 222:252-257.

Celades I, Moliner-Salvador R, Ros-Dosda T, Monfort E and Zaera V. Environmental development of the spanish ceramic tile manufacturing sector over the period 19922007. Boletin De La Sociedad Espanola De Ceramica Y Vidrio 2012; 51:111-118.

Chappell WR, Abernathy CO, Calderon RL and Thomas DJ, Eds. Arsenic exposure and health effects v. Proceedings of the fifth international conference on arsenic exposure and health effects, july 14-18, 2002. Fifth international conference on arsenic exposure and health effects 2003. San Diego, California.

CNE. Centro nacional de epidemiología.2011.

Cohen SM, Arnold LL, Eldan M, Lewis AS and Beck BD. Methylated arsenicals: The implications of metabolism and carcinogenicity studies in rodents to human risk assessment. Critical Reviews In Toxicology 2006; 36:99-133.

Delgado-Saborit JM and Esteve-Cano V. Field comparison of passive samplers versus uvphotometric analyser to measure surface ozone in a mediterranean area. J Environ Monit 2007; 9:610-615.

Diaz-Villasenor A, Burns AL, Hiriart M, Cebrian ME and Ostrosky-Wegman P. Arsenicinduced alteration in the expression of genes related to type 2 diabetes mellitus. Toxicology And Applied Pharmacology 2007; 225:123-133.

Directive 1999/30/EC of the European Parliament and of the Council of 22 April 1999 relating to limit values for sulphur dioxide, nitrogen dioxide and oxides of nitrogen, particulate matter and lead in ambient air.

Directive 2004/107/EC of the European Parliament and of the Council of 15 December 2004 relating to arsenic, cadmium, mercury, nickel and polycyclic aromatic hydrocarbons in ambient air.

Duker AA, Carranza EJM and Hale M. Arsenic geochemistry and health. Environment International 2005; 31:631-641.

Englyst V, Lundstrom NG, Gerhardsson L, Rylander L and Nordberg G. Lung cancer risks among lead smelter workers also exposed to arsenic. Science of the Total Environment 2001; 273:77-82.

Esteve V and Peris G. Ionic characterization of size fractionated airborne tropospheric particulate at castellón (spain). Journal of Aerosol Scence 2000; Suppl. 1:S346-S347.

Esteve V and Ramos A. Materiales para la decoración cerámica. Recomendaciones para su correcta manipulación 1999.

Fang GC, Chang CN, Wu YS, Fu PPC, Yang DG and Chu CC. Characterization of chemical species in pm2.5 and pm10 aerosols in suburban and rural sites of central taiwan. Science of the Total Environment 1999; 234:203-212.

Fernandez-Camacho R, Rodriguez S, de la Rosa J, de la Campa AMS, Viana M, Alastuey A, et al. Ultrafine particle formation in the inland sea breeze airflow in southwest europe. Atmospheric Chemistry and Physics 2010; 10:9615-9630. 
Figueroa DA, Rodriguez-Sierra CJ and Jimenez-Velez BD. Concentrations of ni and v, other heavy metals, arsenic, elemental and organic carbon in atmospheric fine particles (pm2.5) from puerto rico. Toxicology And Industrial Health 2006; 22:87-99.

Halek F, Keyanpour-Rad M, Darbani RM and Kavousirahim A. Concentrations and source assessment of some atmospheric trace elements in northwestern region of tehran, iran. Bulletin Of Environmental Contamination And Toxicology 2010; 84:185-190.

Hayes RB. The carcinogenicity of metals in humans. Cancer Causes \& Control 1997; 8:371385.

He ZLL, Yang XE and Stoffella PJ. Trace elements in agroecosystems and impacts on the environment. J Trace Elem Med Biol 2005; 19:125-140.

Hetland RB, Refsnes M, Myran T, Johansen BV, Uthus N and Schwarze PE. Mineral and/or metal content as critical determinants of particle-induced release of il-6 and il-8 from a549 cells. Journal of Toxicology and Environmental Health-Part A 2000; 60:47-65.

Ho KF, Lee SC, Yu JC, Zou SC and Fung K. Carbonaceous characteristics of atmospheric particulate matter in hong kong. Science of the Total Environment 2002; 300:59-67.

Holmes CW and Miller R. Atmospherically transported elements and deposition in the southeastern united states: Local or transoceanic? Applied Geochemistry 2004; 19:1189-1200.

IARC. Iarc monographs on the evaluation of carcinogenic risks to humans. Complete list of agents evaluated and their classification. 2009, Retrieved 21st September 2008, 2008, from http://monographs.iarc.fr/ENG/Classification/index.php.

Jomova K, Jenisova Z, Feszterova M, Baros S, Liska J, Hudecova D, et al. Arsenic: Toxicity, oxidative stress and human disease. J Appl Toxicol 2011; 31:95-107.

Lewis AS, Reid KR, Pollock MC and Campleman SL. Speciated arsenic in air: Measurement methodology and risk assessment considerations. J Air Waste Manage Assoc 2012; 62:2-17.

Mandal BK and Suzuki KT. Arsenic round the world: A review. Talanta 2002; 58:201-235.

Marcazzan GM, Vaccaro S, Valli G and Vecchi R. Characterisation of pm10 and pm 2.5 particulate matter in the ambient air of milan (italy). Atmos Environ 2001; 35:46394650.

Minguillon MC, Monfort E, Querol X, Alastuey A, Celades I and Miro JV. Effect of ceramic industrial particulate emission control on key components of ambient pm(10). Journal of Environmental Management 2009; 90:2558-2567.

Navas-Acien A, Sharrett AR, Silbergeld EK, Schwartz BS, Nachman KE, Burke TA, et al. Arsenic exposure and cardiovascular disease: A systematic review of the epidemiologic evidence. American Journal of Epidemiology 2005; 162:1037-1049.

Pacyna EG, Pacyna JM, Fudala J, Strzelecka-Jastrzab E, Hlawiczka S, Panasiuk D, et al. Current and future emissions of selected heavy metals to the atmosphere from anthropogenic sources in europe. Atmos Environ 2007; 41:8557-8566.

Pallares S, Vicente AB, Jordan MM and Sanfeliu T. Study of the levels of concentration of as, cd and ni in a ceramic cluster. Water Air And Soil Pollution 2007; 180:51-64.

Putaud JP, Raes F, Van Dingenen R, Bruggemann E, Facchini MC, Decesari S, et al. European aerosol phenomenology-2: Chemical characteristics of particulate matter at kerbside, urban, rural and background sites in europe. Atmos Environ 2004; 38:25792595.

Querol-Balaguer MA, Delgado-Saborit JM, Ramos-Pino F, Amigó-Descarrega JM and Esteve-Cano V. Chemical charaterization of pm10 airborne particulate matter at the ceramic cluster of castellon (spain). Geophysical Research Letters 2004; 6:6108.

Querol X, Alastuey A, Moreno T, Viana MM, Castillo S, Pey J, et al. Spatial and temporal variations in airborne particulate matter (pm10 and pm2.5) across spain 1999-2005. Atmos Environ 2008; 42:3964-3979. 
Querol X, Alastuey A, Rodriguez S, Plana F, Mantilla E and Ruiz CR. Monitoring of pm10 and pm2.5 around primary particulate anthropogenic emission sources. Atmos Environ 2001; 35:845-858.

Querol X, Alastuey A, Rodriguez S, Viana MM, Artinano B, Salvador P, et al. Levels of particulate matter in rural, urban and industrial sites in spain. Science of the Total Environment 2004a; 334:359-376.

Querol X, Alastuey A, Ruiz CR, Artinano B, Hansson HC, Harrison RM, et al. Speciation and origin of pm10 and pm2.5 in selected european cities. Atmos Environ 2004b; 38:6547-6555.

Querol X, Minguillon MC, Alastuey A, Monfort E, Mantilla E, Sanz MJ, et al. Impact of the implementation of pm abatement technology on the ambient air levels of metals in a highly industrialised area. Atmos Environ 2007; 41:1026-1040.

Rampazzo G, Masiol M, Visin F, Rampado E and Pavoni B. Geochemical characterization of pm10 emitted by glass factories in murano, venice (italy). Chemosphere 2008; 71:2068-2075.

Roy P and Saha A. Metabolism and toxicity of arsenic: A human carcinogen. Current Science 2002; 82:38-45.

Sanchez-Rodas D, Sanchez de la Campa A, Oliveira V and de la Rosa J. Health implications of the distribution of arsenic species in airborne particulate matter. Journal of Inorganic Biochemistry 2012; 108:112-114.

Sanchez de la Campa AM, de la Rosa J, Gonzalez-Castanedo Y, Fernandez-Camacho R, Alastuey A, Querol X, et al. Levels and chemical composition of pm in a city near a large cu-smelter in spain. Journal of environmental monitoring : JEM 2011; 13:127687.

Sanchez de la Campa AM, de la Rosa JD, Sanchez-Rodas D, Oliveira V, Alastuey A, Querol $\mathrm{X}$, et al. Arsenic speciation study of pm2.5 in an urban area near a copper smelter. Atmos Environ 2008; 42:6487-6495.

Tsopelas F, Tsakanika L-A and Ochsenkuehn-Petropoulou M. Extraction of arsenic species from airborne particulate filters - application to an industrial area of greece. Microchemical Journal 2008; 89:165-170.

Vahidnia A, Van der Voet GB and de Wolf FA. Arsenic neurotoxicity - a review. Human \& Experimental Toxicology 2007; 26:823-832.

Vickery W, Moreno A and Monfort E. Influencia de las materias primas borácicas en las emisiones de los hornos de fusión de fritas. Qualicer.1998. Castellon, Qualicer 98: 205-214.

von Schneidemesser E, Stone EA, Quraishi TA, Shafer MM and Schauer JJ. Toxic metals in the atmosphere in lahore, pakistan. Science of the Total Environment 2010; 408:1640-1648.

WHO. Air quality guidelines for europe. 2000, Copenhagen. 